\title{
TINJAUAN YURIDIS TERHADAP DOKUMEN PERJANJIAN PEMBIAYAAN KONSUMEN PT BAF SURAKARTA
}

\author{
Rima Agustina \\ E-mail: rima_agustina56@student.uns.ac.id \\ Mahasiswa Fakultas Hukum Universitas Sebelas Maret Surakarta \\ Ambar Budhisulistyawati \\ E-mail: ambarbudhi@gmail.com \\ Dosen Fakultas Hukum Universitas Sebelas Maret Surakarta
}

\begin{abstract}
This article aims to determine the suitability of the consumer financing agreement made by PT Bussan Auto Finance (BAF) with the regulations stipulated in the Civil Code. As for analyzing these problems is done by using normative methods with approaches used through the statute approach. The legal material analysis technique used by using the syllogism method is by using the deduction method which is the opposite of submitting a major premise and then submits a minor premise and from then draws a conclusion. The results of this study indicate that the consumer financing agreement of PT Bussan Auto Finance (BAF) is in accordance with the terms of the agreement stipulated in the Civil Code. The conditions are as follows: (1) Their agreement is binding, agreement can be seen through the signatures of the parties in the agreement; (2) The ability to make an engagement, the parties must include a National Identity Card (KTP) to prove their skills; (3) A certain subject matter, namely regarding the financing of a motorized vehicle; (4) A reason that is not prohibited, the financing made is a reason that is lawful and does not conflict with the law. Then the agreement is valid and binding and applies as a law for the parties who make it.
\end{abstract}

Keywords: Agreement; Consumer Financing Agreement; Financing Company.

\begin{abstract}
Abstrak
Artikel ini bertujuan untuk mengetahui kesesuaian antara perjanjian pembiayaan kosumen yang dibuat oleh PT Bussan Auto Finance (BAF) dengan peraturan yang diatur dalam KUH Perdata. Adapun untuk menganalisis permasalahan tersebut dilakukan dengan menggunakan metode normatif dengan pendekatan yang digunakan melalui pendekatan undang-undang (statute approach). Teknik analisis bahan hukum yang digunakan dengan menggunakan metode silogisme yaitu dengan penggunaan metode deduksi yang bepangkal dari pengajuan premis mayor kemudian diajukan premis minor dan dari kemudian ditarik suatu kesimpulan. Hasil penelitian ini menunjukkan bahwa perjanjian pembiayaan konsumen PT Bussan Auto Finance (BAF) telah sesuai dengan syarat-syarat perjanjian yang diatur dalam KUH Perdata. Adapun syarat-syarat tersebut adalah sebagai berikut: (1) Kesepakatan mereka yang mengikatkan diri, kesepakatan dapat dilihat melalui tanda tangan para pihak dalam perjanjian; (2) Kecakapan untuk membuat perikatan, para pihak wajib mencantumkan Kartu Tanda Penduduk (KTP) untuk membuktikan kecakapannya; (3) Suatu pokok persoalan tertentu, yakni mengenai pembiayaan sebuah kendaraan bermotor; (4) Suatu sebab yang tidak terlarang, pembiayaan yang dilakukan tersebut merupakan suatu sebab yang halal dan tidak bertentangan dengan undang-undang. Maka perjanjian tersebut sah dan mengikat serta berlaku sebagai undang-undang bagi para pihak yang membuatnya.
\end{abstract}

Kata Kunci: Perjanjian; Perjanjian Pembiayaan Konsumen; Perusahaan Pembiayaan

\section{A. Pendahuluan}

Perkembangan era globalisasi dalam masyarakat dari tahun ke tahun berlangsung secara cepat. Seiring dengan perkembangan jaman dan teknologi tersebut semakin banyak pula kebutuhan yang diperlukan oleh masyarakat. Perkembangan teknologi modern ini menghasilkan produk-produk 
baru yang lebih canggih. Hal ini sangat berpengaruh bagi masyarakat, dengan adanya produkproduk baru yang canggih tersebut mendorong masyarakat tergiur untuk memilikinya walaupun secara finansial dana untuk membeli tidak mencukupi. Tuntutan kebutuhan dari masyarakat ini menyebabkan peningkatan permintaan dan pendanaan yang diperlukan oleh masyarakat. Namun masyarakat tetap berupaya untuk membeli karena dapat mempermudah pekerjaannya. Salah satunya adalah kendaraan bermotor.

Jenis kendaraan bermotor ini ada 2 (dua) macam, yakni sepeda motor dan mobil. Harga dari motor maupun mobil bagi sebagian masyarakat tertentu ini tidak terjangkau jika dibayarkan secara kontan, karena tidak semua masyarakat Indonesia berpenghasilan yang cukup. Namun masyarakat tetap memerlukan kendaraan ini bagi mereka untuk mempermudah kecepatan mobilitasnya. Di sisi lain, perusahaan kendaraan bermotor (dealer) ingin supaya produknya terjual supaya mendapatkan keuntungan. Maka dari itu muncul Pembiayaan Konsumen untuk membantu masyarakat supaya mendapatkan barang yang diinginkannya tersebut. Kondisi ini yang menyebabkan muncul dan berkembangnya lembaga pembiayaan konsumen sebagai sumber pembiayaan yang alternatif bagi masyarakat, yang membuat masyarakat yang tadinya kesulitan menjadi lebih mudah untuk membeli suatu barang-barang konsumtif yang diperlukannya.

Perusahaan pembiayaan konsumen ini bekerja sama dengan pabrikan atau distributor yang disebut sebagai supplier untuk menyediakan barang bagi masyarakat (konsumen). Perusahaan pembiayaan konsumen terlebih dahulu membayarkan barang yang akan dibeli oleh konsumen kepada pabrikan atau distributornya, kemudian masyarakat (konsumen) membayarkan kepada perusahaan pembiayaan konsumen dengan cara angsuran sesuai dengan kesepakatan yang telah disepakati bersama. Melalui pembiayaan konsumen ini, masyarakat berpenghasilan rendah yang tadinya kesulitan untuk membeli barang secara tunai, akan dapat teratasi.

Pembiayaan konsumen merupakan salah satu modal pembiayaan yang dilakukan oleh perusahaan finansial, di samping kegiatan seperti leasing, factoring, kartu kredit dan sebagainya. Target pasar dari model pembiayaan konsumen in sudah jelas, bahwa para konsumen (Munir Fuady, 1999: 161). Dalam menjalankan perusahaannya, pembiayaan konsumen tidak sematamata memberikan pembiayaannya kepada semua orang. Ada syarat-syarat yang harus dipenuhi oleh calon konsumen untuk dapat mendapatkan pembiayaan ini. Syarat-syarat ini diperlukan agar tidak terjadi wanprestasi di kemudian hari antar pihak. Maka dari itu, perusahaan pembiayaan konsumen ini benar-benar meneliti calon konsumennya supaya nantinya tidak ada pihak yang dirugikan. Pengaturan mengenai perjanjian pembiayaan konsumen ini terdapat dalam KUH Perdata. Seperti syarat sah perjanjian pada umumnya, pembuatan perjanjian harus berdasarkan pengaturan tersebut dan tidak boleh bertentangan dengan peraturan yang berlaku.

Berdasarkan uraian di atas maka penulis tertarik untuk mengkaji lebih dalam mengenai: tinjauan yuridis terhadap dokumen perjanjian pembiayaan konsumen PT BAF Surakarta.

\section{B. Metode Penelitian}

Metode penelitian yang digunakan oleh penulis dalam penulisan hukum (skripsi) ini adalah penelitian hukum normatif. Jenis penelitian yang digunakan dalam penulisan hukum ini adalah jenis penelitian hukum normatif atau dikenal sebagai penelitian hukum doktrinal, yaitu penelitian hukum yang dilakukan dengan cara meneliti bahan pustaka yang terdiri dari bahan hukum primer dan bahan hukum sekunder (Peter Mahmud Marzuki, 2014: 55).

Pendekatan yang digunakan dalam penelitian ini adalah pendekatan undang-undang (statute approach). Pendekatan undang-undang (statute approach) dilakukan dengan menelaah semua undang-undang dan regulasi yang bersangkut paut dengan isu hukum yang sedang ditangani. (Peter Mahmud Marzuki, 2014: 133).

Teknik analisis bahan hukum yang digunakan penulis dalam penelitian ini adalah dengan menggunakan metode silogisme. Sebagaimana silogisme yang diajarkan oleh Aristoteles, penggunaan metode deduksi ini berpangkal dari pengajuan premis mayor. Kemudian diajukan 
premis minor. Dari kedua premis ini kemudian ditarik suatu kesimpulan atau conclusio (Peter Mahmud Marzuki 2014: 89). Premis mayor merupakan aturan hukum, sedangkan premis minor merupakan fakta hukum. Maka dari kedua hal tersebut kemudian ditarik suatu konklusi.

\section{Hasil Penelitian dan Pembahasan}

Perjanjian pembiayaan konsumen merupakan perjanjian yang mengikat dua pihak atau lebih dan mengatur mengenai pembiayaan konsumen. Perjanjian merupakan suatu perikatan yang lahir dari kontrak yang dibuat secara tertulis. Perjanjian ini harus sesuai dengan ketentuan dalam Pasal 1338 KUH Perdata. Dalam KUH Perdata, Perjanjian pembiayaan konsumen diatur dalam Buku Ketiga, Bab II, Pasal 1313 sampai dengan Pasal 1319. Pasal 1319 menyatakan bahwa semua persetujuan, baik yang mempunyai nama khusus maupun yang tidak dikenal dengan suatu nama tertentu, tunduk pada peraturan umum yang termuat dalam bab ini dan bab yang lain. Oleh sebab itu maka Perjanjian Pembiayaan Konsumen terikat oleh semua peraturan umum yang termuat dalam Buku Ketiga KUH Perdata.

Perjanjian Pembiayaan Konsumen PT Bussan Auto Finance (BAF) terdiri dari beberapa bagian, seperti kontrak pada umumnya, yakni bagian pendahuluan, bagian isi, dan bagian penutup. Perjanjian ini terdiri dari 6 halaman yang dilengkapi dengan pasal-pasal untuk mengaturnya secara rinci. Analisis perjanjian apabila dilihat dari segi hukum Perdata, perjanjian pembiayaan konsumen yang dibuat oleh PT Bussan Auto Finance (BAF) sebagai kreditur dengan Tuan Stefanus Chandra sebagai debitur merupakan salah satu bentuk perjanjian baku atau yang sering dikenal dengan kontrak baku, karena dalam hal ini pembuatan perjanjian baik bentuk maupun isinya hanya dibuat atau disusun oleh salah satu pihak sendiri, yakni oleh PT Bussan Auto Finance (BAF) tanpa kesepakatan debitur. Sedangkan debitur hanya menandatangani dan menyetujui saja apa yang telah dibuat oleh kreditur, debitur tidak dapat merubah isi dari perjanjian tersebut. Dalam hal ini maka dapat disimpulkan bahwa perjanjian ini tidak memenuhi syarat sahnya perjanjian yang diatur dalam Pasal 1320 KUH Perdata, dimana telah disebutkan bahwa salah satu syarat sahnya perjanjian harus ada kesepakatan di antara para pihak untuk menentukan isi perjanjian.

Munir Fuady mendefinisikan kontrak baku sebagai suatu kontrak tertulis yang hanya dibuat oleh salah satu pihak dalam kontrak tersebut, bahkan seringkali tersebut sudah tercetak (boilerplate) dalam bentuk formulir tertentu oleh salah satu pihak, yang dalam hal ini ketika kontrak tersebut ditandatangani umumnya para pihak hanya mengisikan data-data informatif tertentu saja dengan sedikit atau tanpa perubahan dalam klausul-klausulnya, dimana pihak lain dalam kontrak tersebut tidak mempunyai kesempatan atau hanya sedikit kesempatan untuk menegosiasi atau mengubah klausul-klausul yang sudah dibuat oleh salah satu pihak tersebut, sehingga sehingga biasanya kontrak baku sangat berat sebelah. Pihak yang kepadanya disodorkan kontrak baku tersebut tidak mempunyai kesempatan untuk bernegoisasi dan berada hanya pada posisi "take it or leave it". Dengan demikian, oleh hukum diragukan apakah benar-benar ada elemen kata sepakat yang merupakan syarat sahnya kontrak dalam kontrak tersebut. (Munir Fuady, 2003: 76)

Namun pada kenyataannya, kreditur maupun debitur telah membubuhkan tandatangannya dalam dokumen perjanjian pembiayaan konsumen tersebut. Walaupun isi perjanjian tersebut telah ditetapkan dahulu secara sepihak oleh perusahaan pembiayaan konsumen. Maka jika kita melihat hal ini, dapat diketahui bahwa salah satu syarat kesepakatan itu telah ada dan terbukti dengan tandatangan dari pihak-pihak yang terlibat di dalamnya.

Perjanjian Pembiayaan Konsumen yang dibuat oleh PT Bussan Auto Finnace (BAF) dapat dikatakan sah di mata hukum jika pembuatan perjanjian ini memenuhi syarat-syarat perjanjian pada umumnya yang terdapat dalam Pasal $1320 \mathrm{KUH}$ Perdata, syarat-syarat tersebut yakni:

1. Kesepakatan mereka yang mengikatkan diri

Kesepakatan mengandung pengertian bahwa para pihak saling menyatakan kehendak masing-masing untuk menutup suatu perjanjian atau pernyataan pihak yang satu "cocok" atau bersesuaian dengan pernyataan pihak yang lain. Pernyataan kehendak tidak selalu 
harus dinyatakan secara tegas namun dapat dengan tingkah laku atau hal-hal lain yang mengungkapkan pernyataan kehendak para pihak. Kesepakatan yang merupakan pernyataan kehendak para pihak dibentuk oleh dua unsur yaitu unsur penawaran dan penerimaan. Penawaran diartikan sebagai pernyataan kehendak yang mengandung usul untuk mengadakan perjanjian. Usul ini mencakup esensalia perjanjian yang akan diutup. Sedangkan penerimaan merupakan persetujuan dari pihak lain yang ditawari (Agus Yudha Hernoko, 2010: 162-163). Pernyataan dari Debitur yang dilakukan secara eksplisit dalam kesepakatan ini dapat dilihat melalui penandatanganan kontrak dalam perjanjian pembiayaan konsumen. Perlu diketahui dikarenakan Debitur dalam hal ini sudah menikah, maka harus mencantumkan persetujuan dari isterinya yang sah. Penyertaan tanda tangan dari para pihak tersebut dilakukan demi kepentingan bersama, para pihak tersebut dianggap mengetahui dan menghendaki terjadinya perjanjian.

Perjanjian pembiayaan konsumen dibuat dalam bentuk tertulis dan merupakan bentuk perjanjian baku, Debitur tidak dapat mengubah isi perjanjian tersebut. Maka dari itu kesepakatan dalam hal ini hanya dilihat dalam penandatanganan para pihak saja, dikarenakan isi perjanjian telah ditetapkan secara sepihak oleh Kreditur. Debitur hanya perlu menerima atau tidak perjanjian tersebut tanpa mengubah isi yang sudah ada di dalamnya.

2. Kecakapan untuk membuat suatu perikatan

Kecakapan dalam hal ini menyangkut orang atau pihak yang terlibat perjanjian. Debitur maupun kreditur harus cakap hukum supaya perjanjian yang dibuat tersebut sah di mata hukum. Menurut Pasal 1329 KUH Perdata setiap orang dianggap cakap hukum kecuali apabila menurut Undang-undang tidak cakap. Orang-orang yang dianggap tidak cakap hukum sudah diatur dalam Pasal 1330 KUH Perdata, yakni :

a. Orang-orang yang belum dewasa;

b. Mereka yang ditaruh di bawah pengampuan;

c. Orang-orang perempuan dalam hal-hal yang ditetapkan oleh undang-undang dan pada umumnya semua orang kepada siapa undang-undang telah melarang membuat perjanjianperjanjian tertentu.

Menurut Pasal $330 \mathrm{KUH}$ Perdata orang yang belum dewasa adalah mereka yang belum genap berusia 21 (dua puluh satu) tahun dan tidak menikah. Berbeda dengan pengaturan dalam Undang-undang Nomor 1 Tahun 1974 tentang Perkawinan Pasal 47 juncto Pasal 50 menyatakan bahwa anak yang berada di bawah kekuasaan orangtua atau wali sampai berusia 18 (delapan belas) tahun. Undang-Undang Nomor 3 Tahun 2014 tentang Perubahan Atas Undang-Undang Nomor 23 Tahun 2002 tentang Perlindungan Anak menyebutkan bahwa anak adalah seseorang yang belum berusia 18 (delapan belas) tahun, termasuk anak yang masih dalam kandungan, sehingga usia dewasa menurut undang-undang ini ialah mereka yang berusia 18 tahun ke atas. Sesuai asas lex posteriori derogate lege priori, maka undang-undang terbarulah yang harus dijadikan dasar untuk menetukan batas umur kedewasaan tersebut. Karena undang-undang ini bersifat nasional, maka tidak relevan lagi untuk mendikotomi antara kedewasaan yang tunduk pada KUH Perdata dan hukum adat. Dengan demikian batasan umur kedewasaan itu semestinya adalah 18 tahun (Ridwan khairandy, 2013: 178). Pengaturan mengenai pengampuan diatur dalam Pasal 433 KUH Perdata, yang menyebutkan bahwa setiap orang dewasa yang selalu dalam keadaan dungu, sakit otak atau mata gelap harus ditaruh di bawah pengampuan, bahkan ketika ia kadang-kadang cakap menggunakan pikirannya. Seseorang dapat diletakkan di bawah pengampuan jika yang bersangkutan gila, dungu (onoozelheid), mata gelap (razernij), lemah akal (zwakheid van vermogens) atau juga pemboros. Orang yang demikian itu tidak menggunakan akal sehatnya dan oleh karenanya dapat merugikan diri sendiri (RM Pangabean, 2010: 657). Ketentuan mengenai perempuan telah dihapus dengan dikeluarkannya Surat Edaran Mahkamah Agung Nomor 3 Tahun 1963, serta Pasal 31 Undang-Undang Nomor 1 Tahun 1974 tentang Perkawinan yang menyebutkan 
bahwa hak dan kedudukan suami isteri adalah seimbang dan masing-masing berhak untuk melakukan perbuatan hukum.

Perusahaan Pembiayaan Konsumen dalam hal ini merupakan PT Bussan Auto Finance, karena perusahaan ini berbadan hukum PT maka pembuatan perjanjiannya harus diwakili oleh seorang Direktur PT, sedangkan Debitur merupakan perorangan yakni Tuan Stefanus Chandra. Para pihak yang terlibat dalam perjanjian ini harus mencantumkan nomor Kartu Tanda Penduduk (KTP) untuk membuktikan kecakapan para pihak untuk membuat perjanjian. Nomor Kartu Tanda Penduduk (KTP) tersebut dapat digunakan untuk memeriksa identitas para pihak yang bersangkutan. Dengan demikian para pihak ini telah cakap untuk melakukan perbuatan hukum, sehingga syarat kecakapan dalam perjanjian pembiayaan konsumen ini telah terpenuhi. Para pihak harus cakap hukum untuk melakukan suatu perjanjian termasuk perbuatan hukum lainnya.

3. Suatu pokok persoalan tertentu

Adapun yang dimaksud dalam Pasal 1320 KUH Perdata syarat 3 adalah suatu hal tertentu (een bepaald onderwerp). Suatu perjanjian harus memiliki tertentu (certainly of terms) (Ridwan Khairandy, 2013: 186). Objek tertentu bisa diartikan sebagai prestasi yang menjadi pokok kontrak yang bersangkutan. Hal ini untuk memastikan sifat dan luasnya pernyataan-pernyataan yang menjadi kewajiban para pihak. Pernyataan-pernyataan yang tidak dapat ditentukan sifat dan luas kewajiban para pihak adalah tidak atau batal demi hukum (Agus Yudha Hernoko 2013: 191).

Dapat dikatakan dengan kata lain bahwa pokok persoalan tertentu ini merupakan pokok atau objek dari perjanjian. Pasal 1332 juncto Pasal 1334 KUH Perdata menegaskan bahwa pokok perjanjian ini merupakan zaak atau barang baik yang sudah ada maupun barang yang akan ada pada waktu mendatang. Secara umum suatu pokok persoalan tertentu ini menyangkut hak dan kewajiban para pihak yakni hak dan kewajiban Debitur dengan Kreditur. Sedangkan secara khusus, persoalan tertentu ini menyangkut pokok perjanjian yang barangnya dapat dihitung dan ditentukan. Perjanjian pembiayaan konsumen yang dilakukan oleh PT Bussan Auto Finance (BAF) ini menyangkut pembiayaan sebuah kendaraan bermotor bermerek Yamaha Mio-M3 125 Bluecore. Maka dapat disimpulkan bahwa pokok persoalan tertentu dalam hal ini merupakan barang perdagangan yakni sebuah kendaraan bermotor bermerek Yamaha Mio-M3 125 Bluecore. Perhitungan biaya mengenai objek tersebut juga telah diatur secara rinci dalam Perjanjian Pembiayaan Konsumen.

4. Suatu sebab yang tidak terlarang

Suatu sebab dapat dikatakan sebagai isi dari perjanjian dan harus merupakan sebab yang halal serta tidak bertentangan dengan Undang-undang. Suatu sebab adalah terlarang apabila bertentangan dengan undang-undang, kesusilaan dan ketertiban umum. Hal ini juga diatur dalam Pasal 1335 jo 1337 KUH Perdata. Penilaian mengenai kesusilaan ini sangat abstrak, karena bisa berbeda-beda antar satu daerah dengan daerah lainnya. Sedangkan mengenai ketertiban umum menurut J. Satrio memaknai ketertiban umum sebagai hal yang berkaitan dengan masalah kepentingan umum, keamanan negara, keresahan dalam masyarakat dan juga keresahan dalam ketatanegaraan (Ridwan Khairandy, 2013: 191).

Hal ini dilakukan untuk menghindari terjadinya kecurangan atau wanprestasi yang dilakukan oleh salah satu pihak. Sehingga dalam membuat perjanjian pembiayaan konsumen, perusahaan pembiayaan tidak boleh membuat dengan sewenang-wenang. Namun tetap harus berlandaskan oleh peraturan-peraturan yang berlaku. Perjanjian pembiayaan konsumen ini berawal dari suatu sebab, yakni pembiayaan konsumen yang dilakukan oleh Kreditur sebagai pihak yang memberikan pembiayaan kepada Debitur yang memerlukan bantuan pembiayaan untuk membeli benda konsumtif dari suatu perusahaan yaitu sebuah kendaraan bermotor. Suatu sebab yang didapatkan dalam hal ini sudah jelas dan merupakan sebab yang halal. 
Dari penjelasan di atas dapat disimpulkan bahwa Perjanjian Nomor 320010095048 yang dibuat oleh PT Bussan Auto Finance (BAF) telah memenuhi segala syarat sah perjanjian yang diatur dalam pasal $1320 \mathrm{KUH}$ Perdata. Maka oleh karenanya perjanjian ini dianggap sah dan mengikat bagi para pihak yang terlibat di dalamnya. Perjanjian yang sah dapat berlaku sebagai undangundang bagi para pihak yang terlibat di dalamnya. Dengan kata lain, perjanjian yang diperbuat secara sah berlaku seperti berlakunya undang-undang bagi para pihak yang membuatnya (Pasal 1338 ayat 1 dan ayat 2) KUH Perdata. Artinya, para pihak harus mentaati apa yang telah mereka sepakati bersama (Niru Anita Sinaga, 2018: 116).

\section{Simpulan}

Suatu perjanjian dapat dikatakan sah dan mengikat para pihak apabila perjanjian tersebut memenuhi syarat-syarat perjanjian yang diatur dalam Pasal $1320 \mathrm{KUH}$ Perdata dengan tidak melanggar ketentuan-ketentuan lain yang diatur dalam perundang-undangan yang berlaku. Syaratsyarat tersebut antara lain:

1. Kesepakatan mereka yang mengikatkan diri

Kesepakatan para pihak dalam perjanjian pembiayaan konsumen yang dibuat oleh PT Bussan Auto Finance (BAF) dapat dilihat melalui tanda tangan yang telah dibubuhkan oleh para pihak bersangkutan.

2. Kecakapan untuk membuat suatu perikatan

Kreditur yakni perusahaan pembiayaan konsumen PT Bussan Auto Finance dalam melakukan tindakan hukumnya diwakili oleh seorang direktur, sedangkan Debitur merupakan perorangan. Kedua pihak tersebut dalam melakukan tindakan hukum harus sesuai dengan peraturan dan tidak boleh melanggar ketentuan yang berlaku. Dalam hal ini para pihak tersebut wajib mencantumkan Kartu Tanda Penduduk (KTP) untuk membuktikan kecakapan para pihak dalam melakukan tindakan hukum.

3. Suatu pokok persoalan tertentu

Suatu pokok persoalan tertentu menyangkut pokok perjanjian pembiayaan konsumen. Pokok persoalan tertentu dalam hal ini merupakan barang perdagangan sebuah kendaraan bermotor yang perhitungan mengenai biaya objek tersebut telah diatur dalam perjanjian pembiayaan konsumen PT Bussan Auto Finance.

4. Suatu sebab yang tidak terlarang

Hal ini berkaitan dengan pembiayaan konsumen yang diberikan oleh PT Bussan Auto Finance sebagai kreditur dengan Tuan Stefanus Chandra sebagai debitur.

Perjanjian pembiayaan konsumen yang dibuat oleh PT Bussan Auto Finance (BAF) tersebut telah memenuhi syarat-syarat perjanjian yang telah diatur dalam Pasal $1320 \mathrm{KUH}$ Perdata. Perjanjian tersebut telah sah dan mengikat serta kekuatan hukumnya sama seperti undang-undang para pihak yang terlibat di dalamnya.

\section{E. Saran}

Penulis harapkan dengan dibuatnya penelitian hukum ini dapat memberikan informasi bagi masyarakat luas tentang perjanjian pembiayaan konsumen terutama yang berkaitan dengan dealer sepeda motor. Bagi PT Bussan Auto Finance (BAF) diharapkan membuat perjanjian dengan keterbukaan, dengan cara menjelaskan isi dari perjanjian yang akan dibuatnya kepada masyarakat yang hendak mengikatkan diri pada perjanjian tersebut. Untuk masyarakat diharapkan lebih teliti dalam membaca perjanjian yang akan ditandatanganinya supaya tidak ada kesalahan yang dapat merugikan para pihak di kemudian hari. 


\section{F. Daftar Pustaka}

\section{Buku:}

Munir Fuady. 1999. Hukum Tentang Pembiayaan dalam Teori dan Praktek. Bandung: PT Citra Aditya Bakti.

Peter Mahmud Marzuki. 2014. Penelitian Hukum Edisi Revisi. Jakarta: Kencana Prenada Media Group.

Agus Yudha Hernoko. 2010. Hukum Perjanjian Asas Proporsional dalam Kontrak Komersial. Jakarta: Prenada Media Group.

Yudha Hernoko. 2010. Hukum Perjanjian. Jakarta : Kencana.

Ridwan Khairandy. 2004. Itikad Baik dalam Kebebasan Berkontrak. Jakarta: Program Pascasarjana Fakultas Hukum Universitas Indonesia

Khairandy. 2013. Hukum Kontrak Indonesia: Dalam Perspektif Perbandingan (Bagian 1). Yogyakarta : FH UII PRESS

\section{Jurnal:}

Anthony Townley, Alan Jones. 2016. "The Role of Emails and Covering Letters in Negotiating A Legal Contract: A Case Sudy from Turkey." English for Specific Purposes. Volume 44. Elsevier B.V.

Benjamin E. Hermalin, Avery W. Katz, Richard Craswell. 2007. "Contract Law”. Handbook of Law and Economics. Volume 1. Elsevier B.V.

Endang Prasetyawati. 2012. "Perlindungan Hukum terhadap Para Pihak dalam Pembiayaan Konsumen". Jurnal IImu Hukum. Volume 8 No. 16 Agustus 2012. Surabaya: Universitas 17 Agustus 1945.

Niru Anita Sinaga "Peranan Asas-asas Hukum Perjanjian dalam Mewujudkan Tujuan Perjanjian" Binamulia Hukum Volume 7 No. 2 Desember 2018. Jakarta: Fakultas Hukum Universitas Dirgantara Marsekal Suryadarma.

RM Pangabean. 2010. "Keabsahan Perjanjian dengan Klausul Baku” Jurnal Hukum Volume 17. No. 4 Oktober 2010. Jakarta: Fakultas Hukum Universitas Bhayangkara.

Umul Khair. 2017. "Analisis Yuridis Perjanjian Pembiayaan Konsumen dan Akibat Hukum Jika Terjadi Wanprestasi dalam Perjanjian Pembiayaan Konsumen di Indonesia". Jurnal Cendekia Hukum. Vol. 3, No 1 September 2017. Padang: Sekolah Tinggi IImu Hukum Putri Maharaja. 